第85回日本内科学会講演会（1988年）

\title{
シンポジウム 内科領域に招けるウイルス感染症
}

6. 抗ウイルス薬

長崎大学熱带医学研究所臨床部門 松本慶蔵

\section{緒言}

ウイルス感染症に対する感染症学的対策は，従 来ワクチンが主流であり，その流れは今日でる变 わっていない，しかし本日の主題であるATLゃ AIDSの病原体のワクチン化はマラリヤ同様に容 易ではない。

しかしながら免疫不全患者や極度の低肺機能者 でのウイルス感染症や後述の成人水痘肺炎等で は, 抗ウイルス薬の必要性が益々痛感されている。 しかも今日の分子生物学的研究はウイルス感染之 増殖を明らかにし，それに伴って抗ウイルス薬の 発展は近年目覚しいものがある。

1. ウイルス感染症の予防と治癔の原則

1) 抗ウイルス薬による予防と治療

2） $\gamma$ グロブリン療法

3) immunomodulater療法

4）合併感染症や他の合併症に対する治療

以上四項目があげられる。ただしすべてのウイ ルス感染症に抗ウイルス薬治療を必要上す可すの ではなく，その必要性はimmunodeficiencyを中心 とした患者背景, 感染ウイルスの種類, 感染の様 式すなわち急性cell-cidal infection, 持続感染, 潜 伏感染とその予後を考慮して行なわれるべきであ

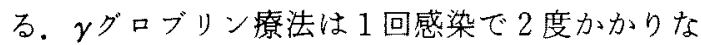
しのウイルス感染症（水痘，麻疹等）に用いられ ることが少なくない。

\section{2. 成人水痘肺炎の 2 症例と抗ウイルス菜治療}

成人水痘”は今日でも15５0\%に肺炎を惹起 乙，その中約半数は入院要し，水痘肺资の 10 20\%は死亡するとされている，著者は当内科 に拈いて近年 2 症例の重症成人水痘肺资経験し

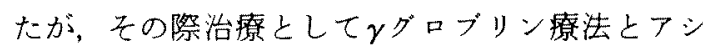
クロビル療法をおの技のに行ない有効な結果を得 た。

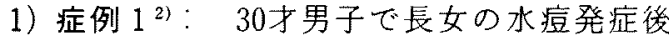
2 週間で長男と共に水痘を発症し，注ぼ同時に高 熱, 血痰, 呼吸困難が生じ当科関連病院に入院し た. 入院時胸部X線像所見では，両側びまん性に浸 潤影とスリガラス様陰影を認めた（入院1985年 7 月 9 日). GOT 127単位, GPT 126単位, LDH 1611 单位, コレステロール0.69 上明らかな肝障害も認

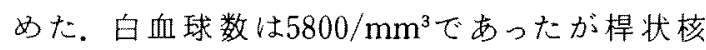
$22 \%$ と左方核移動が認められた。治療としてアル キル処理 $\gamma$ グロブリン治療を開始し，症状は改善 傾向にあったが，7月15日当内科に転医した，7 月18日血痰はなお持続していたが，気管支ファイ バーにより右主気管支に潰瘍と出血像が認められ

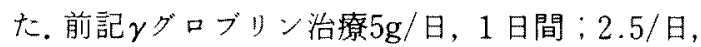
4 日間の治療と抗紐菌性化学療法により着実に病 状は改善し7月25日には胸部X線像も完全に正常 化し, 7 月 9 日 $\mathrm{PaO}_{2}$ 54.5Torr, $\mathrm{AaDo}_{2}$ 53.3て あったものが7月25日88.1Torr, $\mathrm{AaDo}_{2} 8.7$ とほ ぼ正常化し退院した。VZV抗体価はIgMで明確に 陽性であった。

2）症例 2：26才女性, 1986年 4 月28日長女水 痘発症し, 本例は 5 月 10 日定型的水痘疹, 高熱て 発症し，翌日肺炎発症のため当科紹介され，5月 14 日入院した。 入院時口腔内アフタ，体幹部中心 に小膿疮，水痘疮を多数認め，肝 2 横指触知した。 胸部X線像所見では両側末梢に近く小結節様多数 の陰影を認め水痘肺炎と診断した。入院時検査成 績では白血球数 9100 (桿状核 $41 \%$ )，CRP $6+$ ，血

Symposium on Viral infections in medicine. Antiviral agents

Keizo Matsumoto, The Department of Internal Medicine, Institute of Tropical Medicine, Nagasaki University, Nagasaki 
表 1，水豈肺炎における免疫学的辁查

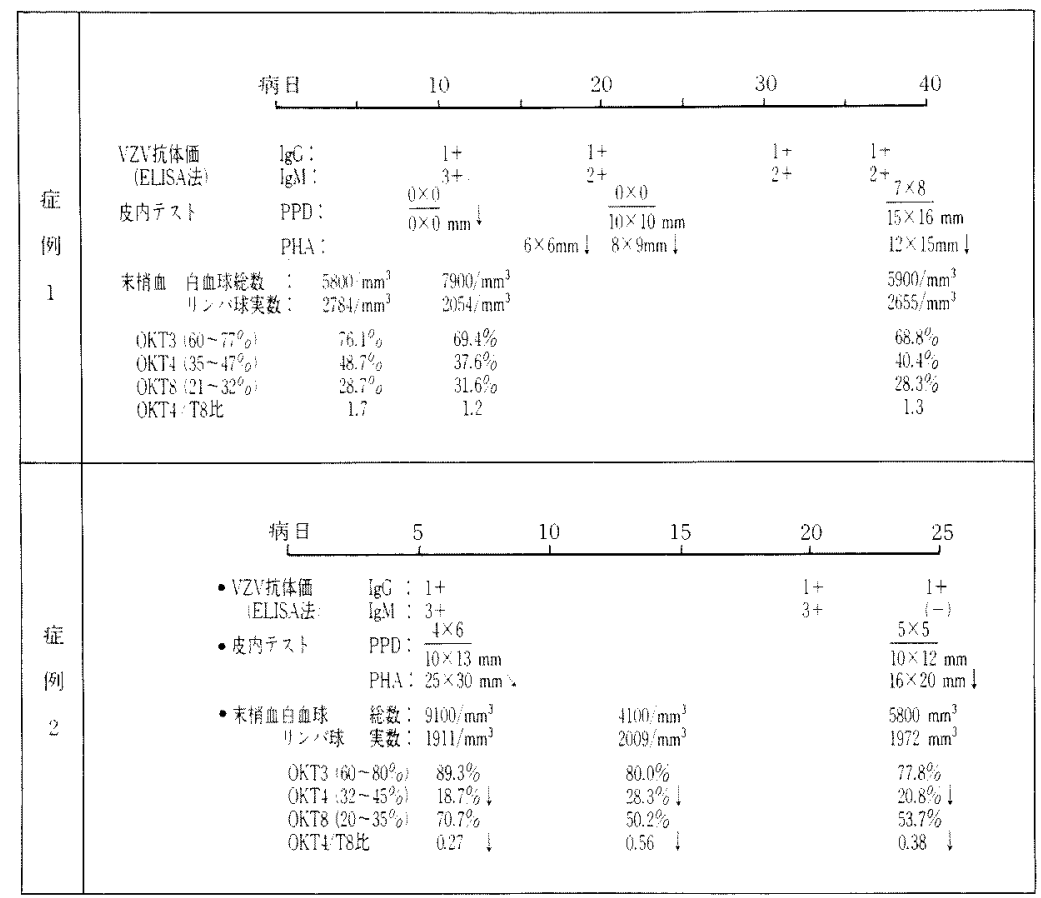

沈60/97mm, GOT 45, GPT 63, LDH 702各単 位, コレステロール0.47, IgMのみ $314.2 \mathrm{mg} / \mathrm{dl}$ と 高值であった。本症の化学療法としてアシクロビ ル (Acyclovir ; ACV) を 1 回 $5 \mathrm{mg} / \mathrm{kg}$ とて 1 日 3 回点滴静注（1週間）とCefotiamの併用を行 なった。翌日より下熱，承疱の消腿，咽頭痛も著 明に改善した，入院時 $\mathrm{PaO}_{2}$ 73.0Torrであったが， 5 月25日諸検查所見はすべて正常值となり，胸部 X線像所見も正常化し，VZV抗体価も入院時 IgM $(3+)$ 退院時 (一) で水痘肺炎と確定され，かつ $\mathrm{ACV}$ 著効例と判定された。

3）水痘肺炎 2 症例に书ける免疫学的検査成 績：表 1 亿示すよらに以上 2 例の成績は共に細 胞性免疫不全を明らかに示しておりこれらの成績 が他疾患の誘発となる可能性もあり，新しい観点 からのウイルス感染症の見直しが必要とされよう.

以上の 2 症例は水痘肺炎こそ抗ウイルス薬の絶 対的適応というべき疾患で， $\gamma$ ロ゙ブリン薬や

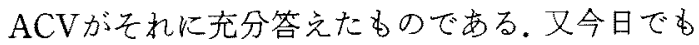
何故に成人水痘が肺炎を薏起し易いかは不明であ る。
3. アシクロビル $(\mathbf{A C V})$ の本邦における使用状況 とその効果アンケート調查による。

今日本邦において最本広く用いられ，副作用も 少なく，作用機序も明らかな抗ウイルス薬にACV がある，上記の水痘肺资に対する効果からる，こ の機会に本薬に関する全国調查を行なうことを企 図した。

1）調查方法： 全国500床以上の総合病院に依 頼し, 昭和 61 年 1 月 1 日から昭和 62 年 12 月 31 日ま での 2 年間に拁け可本菜の使用の有無，対象疾患 とその数, 臨床効果, 副作用並びに今後要望され る抗ウイルス薬の種類について解答を求めた。

2）解答施設：480施設（回収率40\%)

3）使用経験の有無： 有268 $(55.8 \%)$

4）回答使用科名：内科 $421(88.7 \%)$, 小児科 $10(2.1 \%)$ ，皮膚科 $13(2.7 \%)$ ，外科 4 ，麻酔科 2 ，精神科11，複合科19であり，内科以外は同一 病院での内科部長の好意による調査である。

5）対象疾患の内訳は解析可能1801症例である. 帯状疮疹1245症例（69.1\%）と最も多く, ついで HSV脳炎・䯣膜炎 $(9.8 \%)$ ，水痘6.7\%，局所性一 


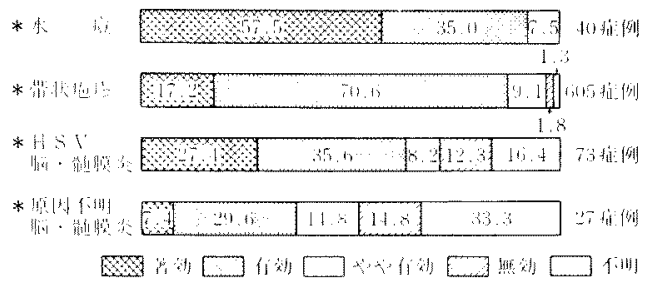

図 1.Acycloviro疾患別有効率

ルペス感染症 $5.7 \%$ ，その他 $(8.7 \%)$ とはCMV感 染21症例含含む原因不明の脳炎，䯣膜炎である。

6) 投与量と投与日数：1 日投与量： 250 $\mathrm{mg} \times 3 /$ 日，点滴が最も多く約 $50 \%$ で，ついで 500 $\mathrm{mg} \times 1 /$ 日；2 $250 \mathrm{mg} \times 2 /$ 日，250mg $\times 1$ 日日順 であり，この4方法で大半を占めた。

投与日数は 1 週間, 5 日間, 10 日間の 3 群が最 む多かっだ。

7) 全体的臨床効果：著効 $26.7 \%$, 有効 $50.1 \%$ で，有効以上の総計は76.8\%上なり，高率であっ た（やや有効 $12.7 \%$ ，無効 $5.6 \%$ ，不明 $4.9 \%$ ).

8）疾患別有効率：調査検討し得た疾患別有 効率を図 1 亿示した。水痘40症例の有効率は，著 効 $57.5 \%$ 之高く，有効 $35.0 \%$ で有効以上の率は $92.5 \%$ に達した。帯状疮疹例は，605症例について 著効 $17.2 \%$, 有効 $70.4 \%$ で有効率は $87.6 \%$ 上同様 高率であった，HSV脳炎・䯣膜炎 73 症例では著効 $27.4 \%$, 有効 $35.6 \%$, 無効例 $12.3 \%$ あり，不明 を除いてみると有効率は上昇するが，有效率は 63\%であった，不明を除いた有効率は43/61 (70.5\%) と上昇する。

以上全体的有効率之疾患別有効率老併世て考光 ると, ACVの有効なHSVおよびVZVの両者の感 染症に十分な効果を示すことが立証された，特に HSV脳炎・䯣膜炎に対し，不明をのぞく61症例で $70.5 \%$ 高い有効率をあげ得たことは注目に值す る.

9）副作用と検查值異常：副作用と検查值異 常の発現率は $5.1 \%$ と低率でから中止を要するも のはなかった。

以上の有効率と副作用を考慮すると VZV, HSV両感染症に対しACVの有用性は高いもので あると結論できる。

\section{4. 将来抗ウイルス薬を必要とするウイルス感染} 症

アンケートに答えられた成績ではHIV (24.3\%)，HTLV-1(23.0\%)，インフルエンザウ イルス $(13.2 \%)$ ，日本脳炎 $(7.1 \%)$, 麻疹 $(6.0 \%)$ 等の感染症等であるが，前 2 者特にレトロウイル 感染症に対する抗ウイルス薬開発への要望が高 い点は今日の現状を良く物語っているものと解さ れる。

5. 現在用いられている抗ウイルス薬と開発中の 抗ウイルス薬の臨床薬理と概況

1) $\mathbf{A C V}^{3)}$ : 作用機序: nucleoside analogueの一種で,ヘルペスウイルス感染細胞に入っ て後ウイルスのもつチミシンキナーゼにより一燐 酸となり，次いで細胞キナーゼにより三燐酸とな るが、この物質はウイルスDNA産生に入り込みそ の産生をストッブさせる。又ACV-1燐酸は直接 DNAポリメラーゼに結合しその酵素活性を阻害 寸る，以上の結果から本薬の化学療法係数はすぐ れ，安全性が高い。ACVの抗ウイルス活性は HSV，VZVに高く，CMVには著しく低い，半減 期は静注法で的 3 時間で, 最高血中濃度は $10 \mathrm{mg}$ / $\mathrm{kg}$ 投与で $90 \mu \mathrm{M}$ である。䯣液移行は血中濃度の約 $50 \%$ あり，HSV脳焱への有効性が理解できる。 唾液中にも血中濃度の $13 \%$ あるる。これらの值は， $50 \%$ 抗ウイルス抑制濃度がHSV： $0.15 \sim 1.62$ $\mu \mathrm{M}$; VZV: $2 \sim 7 \mu \mathrm{M}$; CMV : $25 \sim 300 \mu \mathrm{M}$ であることを考慮するとCMV感染症を除き，本邦 でのHSV，VZV感染症に対するACV投与法と投 与量が適正であったものと推測できる。

本薬は未変化体腎排泄型であるので, 本薬使用 に当たっては腎機能の低下により投与薬物量と投 与間隔を調整する必要がある. ACVのプロドラッ グとして6-Deoxyacyclovir (Descyclovir) が米国 にて検討されている。

$\mathrm{ACV}$ 耐性へルペスウイルスはin vitroでも作ら れ，臨床的にも少数例存在して拀り，今後注目さ れる課題である。

2）CMV感染症に有効な薬物：骨檤移植や腎 移植の普及に伴い, CMV感染症特に肺炎は益々重 要な疾患之なっており，これら疾患に有効な抗り

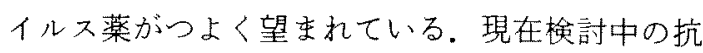




\begin{tabular}{|c|c|c|c|c|c|}
\hline & 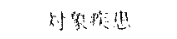 & 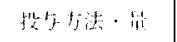 & 然 理 & 缃作化 & 㑑川機Is \\
\hline Anantedine Rimantadies & 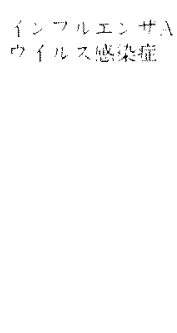 & 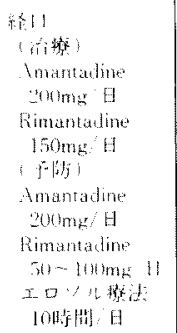 & 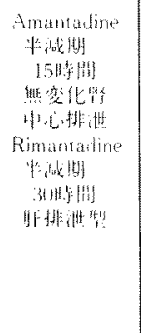 & 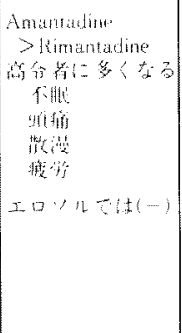 & 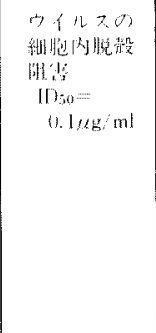 \\
\hline $\begin{array}{l}\text { OH oH } \\
1196)\end{array}$ & 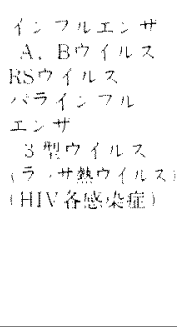 & 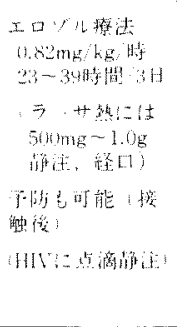 & 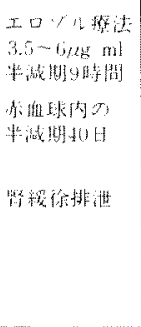 & 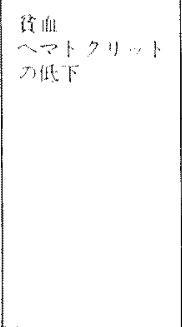 & 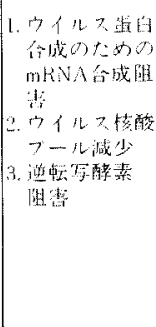 \\
\hline
\end{tabular}

図2、主要呼吸器ウイル不感染症に対する化学潦法

ウイルス薬としてはDHPG (Ganciclovir： ACV 類似構造 $)^{5)}$ 之Interferon $\alpha^{677)}$ 之Interferon $\beta$ の 3 薬がある。DHPGは腎移植後のCMV肺炎に対す る有効性に賛否あるもののAIDSに合併した CMV網膜炎や胃腸炎に有効であったと報告され ている，肺炎に対しては賛否がある。しかし副作 用や毒性がACVに比較しつよい点注意が必要で ある、ヒトInterferon $\alpha$ は腎和植後のCMV感染症

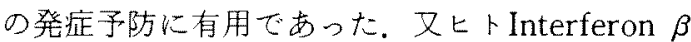
については $2 \times 10^{6}$ 単位の筋注で腎移植後のCMV 肺炎が治癒したとの注目すべき我国での報告影が ある。

3）CMV肺炎を除くいわゆる呼吸器感染症に対 する抗ウイルス薬： 本薬群9110)については一括 して図 2 に緷めた。

4）HIV感染症に有効な莧物群：AIDSに有 効な莧物としてAzidothymidine ${ }^{11}$ が第一にあげ られる。やはり nucleoside analoge(AZT)であり。 その作用機作はHIVの逆転写酵素阻害にあり， 1 日 $250 \mathrm{mg}$ 錠を 4 時間毎に投与する。副作用 ${ }^{12)}$ は貧 血，骨髄障害が节り投与に注意を必要と寸るが，免 疫能の改善, 体重増加, 致命率の改善が認められ た。最近シデオキシ体のddCが臨床娭討中である。 HIV抗体ウイルス薬中硫酸化多糖体やグリチル
サルフェイト13)は本邦で開発されたものである。

おわりに

以上アシクロビル $(\mathrm{ACV})$ の自験例と $\mathrm{ACV} の$ 全 国アンィート調查成績をもとに抗ウイルス薬につ き概説した。

研究協力者：鉿木 寬, 吉田俊昭, 田中宏史, 森戸陖 博, 田尾 操, 秋山盛登司

謝辞 フシクロビルのアンケートに御拹力下さった480 施設の諸先生に深甚の暗意を表する。

\section{文献}

1) Mermelstein $\mathrm{RH}$, et al: Ann Intern Med 55 : 456,1961

2) 隆杉正和, 他: 化学療法D領域 $1: 1047,1985$.

3) Dorsky DI, et al: Ann Intern Med 107:859, 1987.

4) Bean B: Postgraduate Med 80: 109, 1986

5) Bryson $\mathrm{YJ}$ : Clinics Chest Med 7: 453, 1986.

6) Wood MJ, Geddes AM : Lancet II : 1189, 1987.

7) Pomerantz RJ, Hirsh MS: Interferon 9: 113, 1987.

8）高橋公太：化学療法の領域 $2: 202,1986$.

9）北本 治，他：日医新報 $2329: 9,1968$.

10) Gilbert B, Knight V: Antimicro. Agents Chem 30:201, 1986.

11) Fischl MA, et al: New Engl J Med 317: 185 , 1987.

12) Richman DD, et al: New Engl J Med 317:192, 1987.

13）中島秀喜, 山本直樹：エイズジーーナル 1: 30 , 1988. 